\title{
Effect of dietary supplement of sugar beet, neem leaf, linseed and coriander on growth performance and carcass trait of Vanaraja chicken
}

\author{
Punita Kumari, Chandramoni, Kaushalendra Kumar, and Sanjay Kumar
}

Department of Animal Nutrition, Bihar Veterinary College, Patna - 800 014, Bihar, India.

Corresponding author: Punita Kumari, email: puneeta.kri@gmail.com, Ch: chandramoni108@rediffmail.com, KK: drkaushalbvc@gmail.com, SK: sanjayvet29@rediffmail.com

Received: 11-03-2014, Revised: 04-07-2014, Accepted: 10-07-2014, Published online: 02-09-2014

doi: 10.14202/vetworld.2014.639-643 How to cite this article: Kumari P, Chandramoni, Kumar K, Kumar S (2014) Effect of dietary supplement of sugar beet, neem leaf, linseed and coriander on growth performance and carcass trait of Vanaraja chicken, Veterinary World 7(9): 639-643.

\begin{abstract}
Aim: This study was planned to investigate the effect of sugar beet, neem leaf, linseed and coriander on growth parameters such as feed intake, body weight gain, feed conversion ratio (FCR), performance index (PI), and carcass characteristics in broiler birds.

Materials and Methods: The experiment was conducted for a period of 42 days on Vanaraja strain of broiler birds. Different dietary supplement such as sugar beet meal, neem leaf meal, linseed meal and coriander seed meal were used in the basal diet. All day-old 150 male chicks were individually weighed and distributed into five groups having 30 birds in each. Each group was further sub-divided into triplicates having 10 birds in each. Group $T_{1}$ served as control and rest groups $T_{2}, T_{3}, T_{4}$ and $T_{5}$ as treatment groups. Birds in $T_{1}$ group were fed basal ration only, however, $T_{2}, T_{3}, T_{4}$ and $T_{5}$ groups were fed basal ration mixed with $2.5 \%$ sugar beet meal, neem leaf meal, linseed meal, and coriander seed meal individually, respectively.

Results: Broilers supplemented with herbs/spices showed improvement in growth attributes and carcass characteristics. Broilers fed with herbs at the rate of $2.5 \%$ had higher feed intake except sugar beet and coriander seed meal fed group. The body weight and weight gain was also significantly $(\mathrm{p}<0.05)$ higher than control. Both FCR and PI were improved in supplemented groups in comparison to control. Dressing percentage was not significantly $(\mathrm{p}>0.05)$ affected. Average giblet percentage of all supplemented groups were significantly $(p<0.05)$ higher than control and was found to be highest in neem leaf meal fed group. Average by-product percentage was found to be highest in linseed fed group.

Conclusion: Various herbs such as sugar beet, neem leaf, linseed and coriander seed meals affected the growth performance, and carcass trait showed positive inclination toward supplemented groups in broilers. The exact mode of action of these herbs/spices is still not clear, however, one or more numbers of active compounds present in these supplements may be responsible.
\end{abstract}

Keywords: body weight gain, broiler, feed conversion ratio, feed intake, performance index.

\section{I ntroduction}

India has one of the world's largest and fastest growing poultry industries, ranking third in hen egg production [1] and fourth in broiler meat production [2]. According to Annual Report 2011-12 by Department of Animal Husbandry, Dairying and Fisheries, Government of India, poultry population in India is 648.9 million with an annual growth rate of $7.33 \%$. India's per capita consumption of poultry meat and eggs are estimated at around $3 \mathrm{~kg} / \mathrm{annum}$ and 51 eggs/annum, respectively. Industry estimates suggest that broiler meat consumption will double by 2014-15 [3].

Herbs and spices are most important part of the human diet. In addition to boosting flavour, herbs and spices are also known for their preservatives and medicinal value. Sugar beet (Beta vulgaris) is a rich source of carbohydrates, a good source of protein, and possesses high levels of important vitamins, minerals,

Copyright: The authors. This article is an open access article licensed under the terms of the Creative Commons Attributin License (http:// creative commons.org/licenses/by/2.0) which permits unrestricted use, distribution and reproduction in any medium, provided the work is properly cited. and micro-nutrients. It is a good source of dietary fibers, has practically no fat and cholesterol. Diet replacement by 5-10\% with alfalfa grass and sugar beet pulp at starter and grower period in geese was showed a significant effect on live weight. The feeding regime has a significant affect on carcass yield [4]. Neem (Azardica indica) leaves like most tropical tree leaves contain bioactive compounds [5,6], which may affect nutrient utilization. These bioactive compounds may also alter the hematological and serum biochemical parameters of animals. Linseed (Linum usitatissimum) is being consumed as an ingredient in various food formulations as it plays a major role in the field of diet and disease research due to its potential health benefits associated with $\alpha$-linolenic acid (57\%) and its rich phytoestrogens or lignans. Coriander (Coriander sativum) is an umbelliferous annual plant of parsley family. Birds fed with $0.3 \%$ coriander seed diet exhibited the largest body weight gain (BWG), feed conversion ratio (FCR) and carcass yield and decreased feed intake [7].

However, information regarding effects of various feeds such as sugar beet meal, neem leaf meal, linseed meal and coriander seed meal on growth performance and carcass trait in Vanaraja chicken is very 
scanty. Hence, the present study was undertaken to investigate the effect of feeding different dietary supplement on growth performance and carcass trait in Vanaraja chicken.

\section{Materials and Methods}

\section{Ethical approval}

This research work was carried out as per the guidelines in force at the time of carrying out the group experiment. The birds were sacrifices as per standard procedure and protocol.

\section{Experimental birds and design}

The experiment was conducted for a period of 42 days on Vanaraja strain of broiler birds. Feed ingredients were procured in one lot for the whole experiment, and its proximate principles were determined [8] before compounding experimental rations and feed formulation was done [9]. Different ingredients used in the experiment were yellow maize, soya bean meal, fish meal, vitamin, mineral mixture and different dietary supplement like sugar beet meal, neem leaf meal, linseed and coriander seed meal. All day-old 150 male chicks were individually weighed and distributed into five groups having thirty birds in each. Each group was further sub-divided into triplicates having 10 birds in each. Group $\mathrm{T}_{1}$ served as control and rest groups $\mathrm{T}_{2}, \mathrm{~T}_{3}, \mathrm{~T}_{4}$ and $\mathrm{T}_{5}$ as treatment groups. All the standard management practices were followed during whole experimental period including vaccination schedule.

\section{Dietary treatments}

Birds in $\mathrm{T}_{1}$ group were fed basal ration only. However, $\mathrm{T}_{2}, \mathrm{~T}_{3}, \mathrm{~T}_{4}$ and $\mathrm{T}_{5}$ groups were fed basal ration mixed with $2.5 \%$ sugar beet meal, neem leaf meal, linseed meal and coriander seed meal, respectively. Diets

Table-1: Percentage chemical composition and metabolizable energy of feed used in experiment (on DM basis).

\begin{tabular}{|c|c|c|c|c|c|c|c|}
\hline I ngredients & DM & CP & CF & EE & $\mathrm{Ca}$ & $\mathbf{P}$ & $\begin{array}{c}\text { ME kcal/ } \\
\text { kg* }^{*}\end{array}$ \\
\hline Yello & 90 & 8.40 & 2.40 & 2.82 & 0.04 & 0.26 & 3340 \\
\hline $\begin{array}{l}\text { Soyabean } \\
\text { meal }\end{array}$ & 92 & 42.50 & 5.90 & 1.11 & 0.23 & 0.58 & 2300 \\
\hline Fish meal & 91 & 43.10 & 1.70 & 5.60 & 5.20 & 2.10 & 2400 \\
\hline
\end{tabular}

$\mathrm{DM}=$ Dry matter, $\mathrm{CP}=$ Crude protein, $\mathrm{CF}=$ Crude fiber, $\mathrm{Ca}=$ Calcium, $\mathrm{P}=$ Phosphorus, $\mathrm{ME}=$ Metabolizable energy, $\mathrm{EE}=$ Ether extract, $*[16]$

Table-2: Proximate composition of dietary supplements (DM basis).

\begin{tabular}{lcccccc}
\hline Supplements & DM\% & CP\% & EE\% & CF\% & NFE\% & Ash\% \\
\hline Sugarbeet meal & 90 & 9.9 & 0.7 & 20.3 & 55.7 & 3.4 \\
Neemleaf meal & 92.42 & 20.68 & 4.13 & 16.60 & 43.91 & 7.10 \\
Linseed meal & 90 & 40.4 & 3.6 & 10.2 & 28.5 & 7.3 \\
Coriander seed & 93.8 & 12.58 & 9.12 & 37.14 & 26.37 & 8.59 \\
meal & & & & & &
\end{tabular}

$\mathrm{DM}=$ Dry matter, $\mathrm{CP}=$ Crude protein, $\mathrm{CF}=$ Crude fibre, $\mathrm{NFE}=$ Nitrogen free extract were isonitrogenous and isocaloric. Composition of feed is mentioned in Tables 1-4.

\section{Performance and carcass traits}

Feed intake was calculated weekly for each treatment group. At the end of the week, the residual amount of feed was weighed and subtracted from the weight of feed offered at the beginning of the week. Difference in weight was divided by the total number of birds. During the initial phase of the experiment body weight (BW) of individual chicks were recorded. Thereafter, BW change was observed at weekly interval up to 6 weeks. Live weight gain was calculated by subtracting the live weight at the beginning of the week from the live BW of the next week and whole body weight gain (BWG) at the end of $6^{\text {th }}$ week from the initial BW. FCR was calculated every week as the amount of feed consumption per unit of the body gain (average weekly feed consumption (g)/average weekly gain (g)). Performance index (PI) was also calculated weekly. PI was calculated by using the formula [10].

Six birds from each dietary treatment group were slaughtered after $6^{\text {th }}$ week of the experiment by using standard slaughter method. The birds to be slaughter were kept under fasting condition for $24 \mathrm{~h}$ and only water was offered ad lib. Each bird was weighed immediately before slaughter. The birds were bled by giving incision to the jugular vein. The carcass was defeathered and eviscerated. The dressed carcass weight was determined after complete removal of organs and gastrointestinal tract. After recording the dressed weight, various visceral organs like liver, heart and gizzard were separated, respectively. Individual weight of various organs was taken to record eviscerated weight. Giblet weight calculated by adding weight of liver, heart and gizzard, also to calculate giblet percentage. Weight of byproduct was calculated by adding weight of feather, feet and intestine, also to calculate the percentage of byproduct.

\section{Statistical analysis}

All the data were analyzed statistically using Statistical Packages for Social Sciences Software, Version 17.00 (SPSS Inc., Chicago, USA). One-way analysis of variance with the post-hoc Duncan's multiple comparison tests; means were separated using least significant difference to evaluate statistical significance of differences among the control and experimental groups [11]. The results are given as means, standard error and $\mathrm{p}<0.05$ was considered to be statistically significant difference.

\section{Results and Discussion}

The data of different dietary treatments on growth performance and carcass characteristics are presented in Tables 5-7 and Figure-1.

\section{Growth performance}

A good fluctuation was observed in feed intake in every week among different groups. On the whole 
after $6^{\text {th }}$ week average feed intake in $T_{2}$ group and $\mathrm{T}_{5}$ group was found to be significantly $(\mathrm{p}<0.05)$ lower than $T_{1}$ group, whereas value for $T_{4}$ group was found to be highest $(\mathrm{p}<0.05)$ among the group. Feed intake result was in agreement with previous findings $[7,12,13]$. There was a reduced feed intake and growth rate of chickens fed on diets with $2.5 \%$

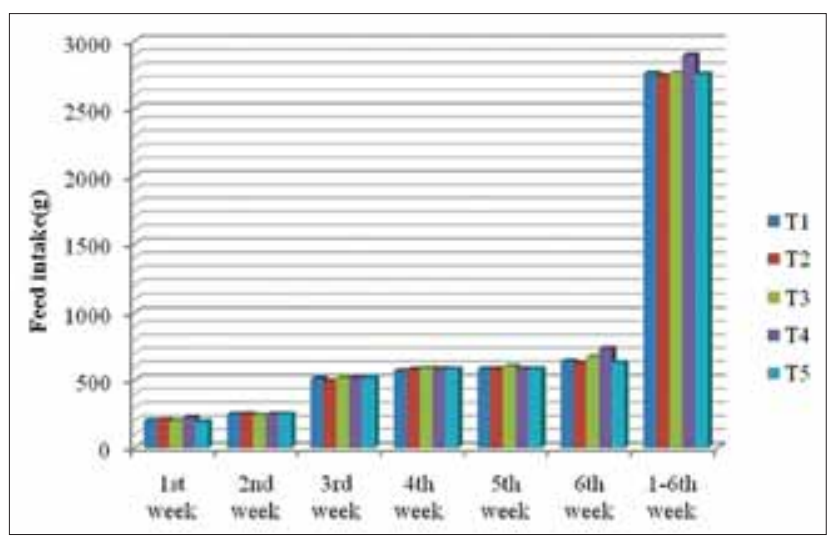

Figure-1: Effect of dietary supplements on average feed intake $(\mathrm{g}) /$ bird at weekly interval and $6^{\text {th }}$ week in broilers. inclusion level of sugar beet meal at $3^{\text {rd }}, 6^{\text {th }}$ and at the end of 6 weeks which may be due to increased satiety and also due to reduced gastric emptying caused by distension of the duodenum which was in agreement with [14]. Average BW at the end of $1^{\text {st }}$ week in linseed fed group $\left(\mathrm{T}_{4}\right)$ was found to be significantly $(\mathrm{p}<0.01)$ higher than other group. Neem leaf meal supplementation ( $T_{3}$ group) in the basal feed also gave significantly higher BW than the control, however, result of other groups were comparable with the control $\left(\mathrm{T}_{1}\right)$. Similar result was noted during $2^{\text {nd }}$ week. This trend continued till the end of the experiment where it was found that linseed meal has a positive effect on BW. A fluctuation was observed in BWG in every week among different groups. Overall BWG in linseed fed group, i.e., $\mathrm{T}_{4}$ was found to be highest, which was statistically similar to neem leaf meal fed group $\left(T_{3}\right)$ and coriander seed meal fed group $\left(\mathrm{T}_{5}\right)$.Chickens usually adopt to fiber-rich diet by increasing the volume of the digestive tract and consequently improve feed intake and growth. This was probably one of the factors involved behind the improved production results

Table-3: Percentage composition of experimental diet for starter.

\begin{tabular}{|c|c|c|c|c|c|}
\hline I ngredients (\% ) & T1 & T2 & T3 & T4 & T5 \\
\hline Yellow maize & 52.75 & 50.25 & 50.25 & 50.25 & 50.25 \\
\hline Soya bean meal & 35.00 & 35.00 & 35.00 & 35.00 & 35.00 \\
\hline Fish meal & 10.00 & 10.00 & 10.00 & 10.00 & 10.00 \\
\hline Mineral mixture & 1.75 & 1.75 & 1.75 & 1.75 & 1.75 \\
\hline Salt & 0.50 & 0.50 & 0.50 & 0.50 & 0.50 \\
\hline Sugar beet meal & - & 2.50 & - & - & - \\
\hline Neem leaf meal & - & - & 2.50 & - & - \\
\hline Linseed meal & - & - & - & 2.50 & - \\
\hline Coriander seed meal & - & - & - & - & 2.50 \\
\hline \multicolumn{6}{|l|}{ Analyzed value } \\
\hline $\mathrm{CP} \%$ & 23.61 & 23.40 & 23.40 & 23.40 & 23.40 \\
\hline ME** & 2806.85 & 2723.35 & 2723.35 & 2723.35 & 2723.35 \\
\hline $\mathrm{Ca}$ & 1.222 & 1.222 & 1.222 & 1.222 & 1.222 \\
\hline $\mathrm{P}$ & 0.556 & 0.554 & 0.554 & 0.554 & 0.554 \\
\hline
\end{tabular}

** Calculated value, $\mathrm{CP}=$ Crude protein, $\mathrm{ME}=$ Metabolizable energy, $\mathrm{Ca}=$ Calcium, $\mathrm{P}=$ Phosphorus

Table-4: Percentage chemical composition of experimental diet for finisher.

\begin{tabular}{|c|c|c|c|c|c|}
\hline I ngredients & T1 & T2 & T3 & T4 & T5 \\
\hline Yellow maize & 60.00 & 60.00 & 60.00 & 60.0 & 60.00 \\
\hline Soya bean meal & 27.75 & 25.25 & 25.25 & 25.25 & 25.25 \\
\hline Fish meal & 10.00 & 10.00 & 10.00 & 10.00 & 10.00 \\
\hline Mineral mixture & 1.75 & 1.75 & 1.75 & 1.75 & 1.75 \\
\hline Salt & 0.50 & 0.50 & 0.50 & 0.50 & 0.50 \\
\hline Sugar beet meal & - & 2.50 & - & - & - \\
\hline Neem leaf meal & - & - & 2.50 & - & - \\
\hline Linseed meal & - & - & - & 2.50 & - \\
\hline Coriander seed meal & - & - & - & - & 2.50 \\
\hline \multicolumn{6}{|l|}{ Analyzed value } \\
\hline СР\% & 21.14 & 20.08 & 20.08 & 20.08 & 20.08 \\
\hline ME** & 2882.25 & 2824.75 & 2824.75 & 2824.75 & 2824.75 \\
\hline $\mathrm{Ca}$ & 1.108 & 1.101 & 1.101 & 1.101 & 1.101 \\
\hline $\mathrm{P}$ & 0.548 & 0.544 & 0.544 & 0.544 & 0.544 \\
\hline
\end{tabular}

** Calculated value. $\mathrm{CP}=$ Crude protein, $\mathrm{ME}=$ Metabolizable energy, $\mathrm{Ca}=$ Calcium, $\mathrm{P}=\mathrm{Phosphorus}$. Composition of mineral mixture=Vitamin A (7,00,000 I.U.), vitamin D3 (70,000 I.U.), vitamin E (250 mg), nicotinamide (1000 mg), cobalt $(150 \mathrm{mg})$, copper $(1200 \mathrm{mg})$, iodine $(325 \mathrm{mg})$, iron $(1500 \mathrm{mg})$, potassium $(100 \mathrm{mg})$, magnesium $(6000 \mathrm{mg})$, manganese (1500 mg), selenium (10 mg), sodium $(5.9 \mathrm{mg})$, sulfur $(0.72 \%)$, zinc (9600 $\mathrm{mg})$, calcium $(25.5 \%)$, phosphorus $(12.75 \%)$ 
Table-5: Effect of dietary supplements of herbs/spices on average BW (g) and average BWG ( $\mathrm{g}$ ) at weekly interval in broilers.

\begin{tabular}{|c|c|c|c|c|c|}
\hline Week & T1 & T2 & T3 & T4 & T5 \\
\hline \multicolumn{6}{|l|}{ BW $(g)$} \\
\hline $1^{\text {st }}$ & $210.00^{\mathrm{a}} \pm 3.22$ & $216.62^{\mathrm{ab}} \pm 3.02$ & $220.19^{b} \pm 3.20$ & $233.20^{\complement} \pm 2.65$ & $216.38^{\mathrm{ab}} \pm 2.66$ \\
\hline $2^{\text {nd }}$ & $347.20^{\mathrm{a}} \pm 5.27$ & $352.73^{a} \pm 5.28$ & $356.04^{\mathrm{a}} \pm 6.48$ & $372.73^{b} \pm 4.90$ & $356.08^{\mathrm{a}} \pm 4.92$ \\
\hline $3^{\text {rd }}$ & $592.29^{a} \pm 10.02$ & $599.15^{\mathrm{a}} \pm 8.62$ & $613.11^{\mathrm{ab}} \pm 9.39$ & $632.48^{\mathrm{b}} \pm 8.35$ & $628.80^{b} \pm 10.79$ \\
\hline $4^{\text {th }}$ & $844.22^{\mathrm{a}} \pm 12.45$ & $881.15^{\mathrm{ab}} \pm 13.54$ & $904.84^{b} \pm 14.65$ & $908.89^{b} \pm 11.22$ & $917.74^{b} \pm 14.38$ \\
\hline $5^{\text {th }}$ & $1117.80^{\mathrm{a}} \pm 14.83$ & $1175.67^{\mathrm{b}} \pm 13.18$ & $1207.58^{\mathrm{b}} \pm 15.66$ & $1207.40^{\mathrm{b}} \pm 16.99$ & $1208.25^{\mathrm{b}} \pm 18.54$ \\
\hline $6^{\text {th }}$ & $1415.20^{\mathrm{a}} \pm 16.98$ & $1500.78^{b} \pm 17.63$ & $1546.44^{b c} \pm 19.89$ & $1574.66^{c} \pm 24.23$ & $1513.55^{b} \pm 19.91$ \\
\hline \multicolumn{6}{|c|}{ BWG $(g)$} \\
\hline $1^{\text {st }}$ & $110.47^{\mathrm{a}} \pm 3.07$ & $114.69^{\mathrm{a}} \pm 3.54$ & $114.79^{\mathrm{a}} \pm 3.67$ & $127.00^{\mathrm{b}} \pm 2.83$ & $113.18^{\mathrm{a}} \pm 3.04$ \\
\hline $2^{\text {nd }}$ & $137.20 \pm 5.69$ & $136.11 \pm 4.61$ & $135.85 \pm 4.83$ & $139.53 \pm 4.18$ & $139.70 \pm 4.47$ \\
\hline $3^{\text {rd }}$ & $245.08^{\mathrm{a}} \pm 8.10$ & $246.41^{\mathrm{a}} \pm 7.98$ & $257.07^{\mathrm{ab}} \pm 8.31$ & $259.75^{\mathrm{ab}} \pm 7.71$ & $272.72^{b} \pm 10.13$ \\
\hline $4^{\text {th }}$ & $251.93^{\mathrm{a}} \pm 7.52$ & $281.99^{b} \pm 9.79$ & $291.73^{b} \pm 10.83$ & $276.42^{\mathrm{ab}} \pm 8.01$ & $288.94^{b} \pm 9.05$ \\
\hline $5^{\text {th }}$ & $273.58^{a} \pm 7.7$ & $294.52^{\mathrm{ab}} \pm 9.52$ & $302.74^{b} \pm 9.60$ & $298.51^{\mathrm{ab}} \pm 10.32$ & $290.51^{\mathrm{ab}} \pm 9.28$ \\
\hline $6^{\text {th }}$ & $297.40^{a} \pm 8.53$ & $325.11^{\mathrm{ab}} \pm 9.66$ & $338.86^{\mathrm{bc}} \pm 12.03$ & $367.26^{c} \pm 16.01$ & $305.29^{\mathrm{ab}} \pm 10.04$ \\
\hline $1-6^{\text {th }}$ & $1315.67^{a} \pm 17.07$ & $1398.84^{b} \pm 17.3$ & $1441.04^{b c} \pm 19.94$ & $1468.46^{c} \pm 24.24$ & $1410.35^{b c} \pm 20.02$ \\
\hline
\end{tabular}

Values with similar superscripts (row wise $-a, b, c, d)$ did not differ significantly $(P>0.05)$. BW=Body weight, BWG=Body weight gain

Table-6: Effect of dietary supplement of herbs/spices on FCR and PI at weekly interval and $6^{\text {th }}$ week in broilers.

\begin{tabular}{|c|c|c|c|c|c|}
\hline Week & T1 & T2 & T3 & T4 & T5 \\
\hline \multicolumn{6}{|l|}{ FCR } \\
\hline $1^{\text {st }}$ & $1.88 \pm 0.05$ & $1.86 \pm 0.06$ & $1.81 \pm 0.06$ & $1.80 \pm 0.04$ & $1.75 \pm 0.05$ \\
\hline $2^{\text {nd }}$ & $1.92 \pm 0.08$ & $1.89 \pm 0.06$ & $1.844 \pm 0.06$ & $1.84 \pm 0.05$ & $1.842 \pm 0.06$ \\
\hline $3^{\text {rd }}$ & $2.15 \pm 0.06$ & $2.06 \pm 0.06$ & $2.07 \pm 0.07$ & $2.04 \pm 0.05$ & $1.96 \pm 0.06$ \\
\hline $4^{\text {th }}$ & $2.32^{b} \pm 0.06$ & $2.13^{\mathrm{ab}} \pm 0.07$ & $2.09^{a} \pm 0.08$ & $2.16^{\mathrm{ab}} \pm 0.06$ & $2.07^{a} \pm 0.06$ \\
\hline $5^{\text {th }}$ & $2.18 \pm 0.06$ & $2.04 \pm 0.07$ & $2.05 \pm 0.06$ & $2.01 \pm 0.06$ & $2.06 \pm 0.06$ \\
\hline $6^{\text {th }}$ & $2.21^{b} \pm 0.06$ & $1.97^{a} \pm 0.05$ & $2.06^{\mathrm{ab}} \pm 0.07$ & $2.10^{\mathrm{ab}} \pm 0.08$ & $2.12^{\mathrm{ab}} \pm 0.06$ \\
\hline $1-6^{\text {th }}$ & $2.11^{\mathrm{b}} \pm 0.03$ & $1.97^{a} \pm 0.02$ & $1.97^{\mathrm{a}} \pm 0.03$ & $1.99^{\mathrm{a}} \pm 0.03$ & $1.96^{\mathrm{a}} \pm 0.03$ \\
\hline \multicolumn{6}{|l|}{ PI } \\
\hline $1^{\text {st }}$ & $61.38 \pm 3.35$ & $65.16 \pm 4.02$ & $67.34 \pm 4.12$ & $72.66 \pm 3.24$ & $67.62 \pm 3.49$ \\
\hline $2^{\text {nd }}$ & $79.05 \pm 6.38$ & $76.56 \pm 5.27$ & $78.93 \pm 5.86$ & $79.90 \pm 4.79$ & $80.38 \pm 5.21$ \\
\hline $3^{\text {rd }}$ & $120.95 \pm 8.67$ & $126.75 \pm 8.34$ & $131.78 \pm 8.57$ & $133.92 \pm 8.32$ & $149.71 \pm 12.77$ \\
\hline $4^{\text {th }}$ & $113.98^{\mathrm{a}} \pm 7.12$ & $141.69^{b} \pm 9.96$ & $150.58^{b} \pm 11.09$ & $134.18^{\mathrm{ab}} \pm 7.59$ & $147.55^{b} \pm 9.19$ \\
\hline $5^{\text {th }}$ & $131.33 \pm 7.51$ & $153.21 \pm 9.84$ & $156.45 \pm 10.36$ & $158.05 \pm 12.12$ & $149.05 \pm 9.80$ \\
\hline $6^{\text {th }}$ & $141.06^{\mathrm{a}} \pm 8.21$ & $172.86^{\mathrm{ab}} \pm 10.75$ & $176.37^{\mathrm{ab}} \pm 12.90$ & $193.37^{b} \pm 18.70$ & $152.61^{\mathrm{a}} \pm 10.52$ \\
\hline $1-6^{\text {th }}$ & $629.81^{\mathrm{a}} \pm 16.53$ & $716.69^{b} \pm 17.64$ & $738.86^{\mathrm{b}} \pm 20.11$ & $750.89^{b} \pm 24.98$ & $726.23^{b} \pm 20.77$ \\
\hline
\end{tabular}

Values with similar superscripts (row wise $-a, b, c, d$ ) did not differ significantly $(P>0.05)$, FCR=Feed conversion ratio, $\mathrm{PI}=$ Performance index

Table-7: Effect of dietary supplement on carcass quality at $6^{\text {th }}$ week in broiler.

\begin{tabular}{lccccc}
\hline Attributes & T1 & T2 & T3 & T4 & T5 \\
\hline Dressing percent & $71.88 \pm 0.76$ & $73.58 \pm 0.74$ & $72.39 \pm 0.90$ & $73.47 \pm 0.73$ & $73.31 \pm 0.66$ \\
Giblet percent & $6.40^{\mathrm{a}} \pm 0.21$ & $7.52^{\mathrm{c}} \pm 0.12$ & $7.70^{\mathrm{c}} \pm 0.20$ & $6.57^{\mathrm{ab}} \pm 0.18$ & $6.99^{\mathrm{b}} \pm 0.06$ \\
Byproduct percent & $31.41^{\mathrm{a}} \pm 0.41$ & $31.06^{\mathrm{a}} \pm 0.39$ & $33.30^{\mathrm{b}} \pm 0.41$ & $33.52^{\mathrm{b}} \pm 0.26$ & $30.82^{\mathrm{a}} \pm 0.31$ \\
\hline
\end{tabular}

Values with similar superscripts (row wise - $a, b, c, d$ ) did not differ significantly ( $P>0.05$ )

with treatment groups than the control. Higher weight gain may be due to increased nitrogen retention in supplemented groups than the control. Sugar beet fed group also gave statistically better result than the control group and result was in agreement with the observation of $[4,7,13]$ but [15] did not report any change in BWG fed on neem leaf meal. Statistical difference in case of FCR was noted during $4^{\text {th }}$ and $6^{\text {th }}$ week only showing better effect of coriander seed meal. These finding of FCR agree with the result of $[7,13]$. Statistical difference in case of PI was also noted during $4^{\text {th }}$ and $6^{\text {th }}$ week showing better effect of linseed meal. At the end of the experiment, finding of both FCR and PI suggest that there was significant difference between control and supplemented group, however, among supplemented groups, difference was not significant.

\section{Carcass characteristics}

Dressing percentage was also affected but not significantly by the supplementation of different additive, herbs/spices during the experiment which was in agreement with the observation of [7,15]. Average giblet percentage was found to be highest in $\mathrm{T}_{3}$ group, whereas, $\mathrm{T}_{2}$ group giblet percentage was also significantly $(\mathrm{p}<0.05)$ higher than $\mathrm{T}_{4}$ and $\mathrm{T}_{5}$ group. Result of giblet percentage was in agreement with the observation 
of [15]. Average byproduct percentage was found to be highest in $\mathrm{T}_{4}$ group. There was no significant difference among $T_{1}, T_{2}$ and $T_{5}$ groups, and $T_{3}$ and $T_{4}$ groups were statistically similar in byproduct percentage.

\section{Conclusion}

It is concluded from the present study that sugar beet, neem leaf, linseed and coriander seed meals have a positive effect on growth performance and carcass characteristics of broilers. Hence, feeding of above herbs/spices in broiler ration may be helpful in better performance and carcass yield of broiler, but no definite trend was shown by different treatment group. However, further studies are required to know the exact mode of action of these herbs/spices and actual bioactive compounds present in these supplements accelerate the metabolic activity of broiler birds.

\section{Authors' Contributions}

PK carried out the experiment and drafted the final manuscript. $C$ designed the experiment, guided during the experiment. KK helped in the analysis of the data. SK scientifically corrects the manuscript. All authors read and approved the final manuscript.

\section{Acknowledgments}

The authors express their gratitude to the Principal, Bihar Veterinary College, Patna, India for providing the facilities for conducting this experiment. The authors are thankful to Bihar Agricultural University, Sabour, Bhagalpur, Bihar, India for providing necessary fund for this study.

\section{Competing I nterests} interests.

The authors declare that they have no competing

\section{References}

1. USDA. (2011) International Egg and Poultry Review. Vol. 14. No. 34, United States Department of Agriculture, Washington, DC.

2. ICRA Rating Feature. (2011) Poultry Industry-broiler
Meat and Table Egg. ICRA Limited, Associate of Moody's Investors Service. p. 1-9.

3. Global Agricultural Information Network Report, (2011) IN1205.http://gain.fas.usda.gov/Lists/Advanced\%20 Search/AllItems.aspx. [Last accessed on 2014 Jun 28].

4. Arslan, C. and Saatci, M. (2003) Bulky feeds in the intensive fattening of goslings. Revue Méd. Vét., 154(10): 633-638.

5. Kausik, B., Ishita, C., Ranajit, K.B., and Uday, B. (2002) Biological activities and medicinal properties of Neem (Azadirachta indica). Curr. Sci., 82(11): 1336-1344.

6. Akpan, M.J., Enyenihi, G.E., Obasi, O.L., Solomon, I.P. and Udedibie, A.B.I. (2008) Effects of dietary neem leaf extract on the performance of laying hens. Proceedings of $33^{\text {rd }}$ Annual Conference Nigerian Society Animal Production, March 20-25, p. 396-398.

7. Saeid, J.M. and Al-Nasry, A.S. (2010) Effect of dietary coriander seeds supplementation on growth performance carcass traits and some blood parameters of broiler chickens. Int. J. Poult. Sci., 9(9): 867-870.

8. AOAC. (2000) Official Method of Analysis. $16^{\text {th }}$ ed. Association of Analytical Chemists, Washington, D.C.

9. BIS. (1991) Poultry feeds specification. Bureau of Indian Standards, New Delhi, India.

10. Bird, H.R. (1955) Performance index of growing chickens. Poult. Sci., 34: 1163-1164.

11. Snedecor, G.W. and Cochran, W.G. (1980) Statistical Methods, SXVII. 507. The Iowa State Univ. Press, Ames, USA.

12. Hlkansson, J., Eriksson, S. and Svensson, S.A. (1978) The influence of feed energy level on feed consumption, growth and development of different organs of chicks. Report 57. Swedish University of Agricultural Sciences, Uppsala. p. $1-54$.

13. Pettersson, D and Razdan, A. (1993) Effects of increasing levels of sugar-beet pulp in broiler chicken diets on nutrient digestion and serum lipids Br. J. Nutr. 70(1): 127-137.

14. Sellers, A.F. (1977) Genesis and propagation of motor activity in the digestive tract. In: Swenson, M.J. editor. Duke's Physiology of Domestic Animals. Ithaca, New York: Comstock Pub. Associates. p. 233-239.

15. Esonu, B.O., Opara, M.N., Okoli, I.C., Obikaonu, H.O., Udedibie, C. and Iheshiulor, O.O.M. (2006) Physiological response of laying birds to neem (Azadirachta indica) leaf meal-based diets: Body weight, organ characteristics and haematology. J. Health Alli. Sci., 2: 4. Available from: http://www.ojhas.org/issue18/2006-2-4.htm.

16. Reddy, D.V. (2007) Applied Nutrition (Livestock, Poultry, Human, Pet, Rabbit and Laboratory Animal Nutrition). Oxford \& IBH Publishing Co. Pvt. Ltd., New Delhi. p. 146. 